\title{
The Nutrition of Male Industrial Workers with Particular Reference to Intake and Expenditure of Calories
}

\author{
By E. R. BRANSBY \\ Ministry of Health, 23 Savile Row, London, W. I
}

(Received 25 September 1953)

A previous pilot study (Ministry of Health, 1950) showed that calorie intake did not on the average vary between groups of men doing work of different degrees of activity. The result was contrary to what might have been expected; the present larger study was made to investigate further the relationship between heaviness of work and calorie intake. Another object was to develop survey methods for assessing the proportions of the calorie intake spent by industrial workers on various activities. The opportunity was taken during the survey of collecting certain medical and physiological data for industrial workers. The objects of the study, which was a new development in the survey field, were in general successfully achieved. The study showed that the necessary information could be collected by survey methods, but that there are difficulties in interpretation and that, in particular, further study of job assessment and more data on standards of calorie expenditure for various activities are required.

\section{Sample and information collected}

\section{METHODS}

The men included in the survey worked in fifteen factories at Slough. Dr Austin Eagger, Director of the Slough Industrial Health Service, approached the managements of a number of factories on the Slough Trading Estate, and Miss G. M. Warnock and the author explained the nature of the survey to them. A selection was made of jobs thought suitable for study and some of the men working on these jobs were invited to co-operate. No attempt was made to obtain a random sample of men engaged on particular jobs or in particular factories.

\section{Medical examination}

Each subject was given a medical examination and assessment was made of his state of health and nutrition. Height, weight, blood pressure and skinfold measurements were taken. Samples of blood were drawn for estimating haemoglobin and pseudocholinesterase (cf. Berry, Cowin \& Davies, I954). The medical examinations were made by Dr W. T. C. Berry and Dr P. J. Cowin.

\section{Job assessment}

An ordinary industrial classification in terms of heaviness was made of each job by Dr A. I. G. McLaughlin, H.M. Inspector of Factories, and Mr N. L. Ford, H.M. District Inspector of Factories. The classification was empirical but in general was 
related to the physical energy expended during the shift. In making the assessments, account was taken of the following factors:

(I) Individual and total weights lifted and handled, and the heights to which they were raised.

(2) The method of lifting, that is, whether or not mechanical aids were used.

(3) The speed and periodicity of the work and rest pauses.

(4) The length of the working shift and whether or not overtime was worked.

(5) Whether or not there were complaints of fatigue at the end of the day's work.

The following are examples of the grading of the job:

Light: filler (tooth brushes), rotary-machine operator, polisher.

Light to medium: press operator (cutting machine), bandsaw machinist, gelatine mixer.

Medium: cooker operator (confectionery), pattern maker, card stripper.

Medium to heavy: core maker, sawing machinist (steel), maintenance fitter.

Heavy: moulder, packer and loader, guillotine operator.

\section{Record of out-of-factory activities}

The subjects were asked to provide for I week a record of their out-of-factory activities. Each man was given a sheet on which were listed certain key points of the day, such as time of getting up, of breakfast, of leaving for work, and of arrival at work, and so on. There was space to record also information on the method of travelling, for example, whether the subject walked or went by bus or train and, if so, whether he stood or sat. The subject was interviewed in the factory every day in the week he was studied, the information he had recorded was examined and checked, and the timetable for the whole day completed. At the week-end the men were visited in their homes to check the information recorded.

\section{Record of food consumption}

A record was obtained of the food eaten inside and outside the home and the beer drunk by each subject for I week. The record of the home diet was collected by the weighing method of Widdowson (1936) and of Beltram \& Bransby (1950), but measuring glasses were provided for measuring liquids. The wife or mother made the measurements and kept the records; she was visited almost every day by a field worker to ensure that the information was being properly recorded. No record had to be discarded as unsatisfactory. In each factory where there was a canteen, samples of the food served during the period were weighed on each day that the survey was being made in that factory. The men in one factory had their midday meal in two neighbouring cafés, and the proprietress of each café kept the necessary records. In another factory the men ate in a neighbouring one and, again, the weights of the foods provided were obtained. The men on being interviewed about their out-of-factory activities were asked to say also what beer they had drunk. 


\section{Field procedure and numbers studied}

The first step in the survey was the medical examination; it was followed by the dietary survey and the record of out-of-factory activities, which were made during the same week. Later, the job assessments were made*. The field work of the survey took place during the latter part of January and during February and March 1952.

Of the 174 men who were medically examined, not all provided clinical results. Height, weight and skinfold measurements were obtained for $15 \mathrm{I}$ men, haemoglobin values for I49, systolic blood pressure for $\mathrm{I}_{47}$, diastolic blood pressure for $\mathrm{I}_{42}$ and pseudo-cholinesterase values for 130 . Full information on diet and on out-of-factory activities was collected for $152 \mathrm{men}$. There was thus a loss of twenty-two between the medical examination and the food survey. The reasons for the losses are shown in Table I. Of the 152 men remaining, fifteen were excluded from the study of calorie intake and expenditure because the medical examination revealed some condition, generally slight, that might have had an effect on metabolism or activity. That part of the study was therefore confined to 137 men, all of whom could be presumed fit.

\section{Table I. Reasons of twenty-two subjects for withdrawing from the survey}

$\begin{array}{lc}\text { Reason for withdrawing } & \begin{array}{c}\text { No. of } \\ \text { subjects }\end{array} \\ \text { Illness at home } & 5 \\ \text { Illness during survey } & \text { I } \\ \text { Left firm during survey } & 3 \\ \text { Parent too old } & 4 \\ \text { Wife (or mother) at work } & 8 \\ \text { Parent away from home } & \text { I }\end{array}$

Five women field workers made the food survey, one man and one woman collected the information on out-of-factory activities, one man supervised the weighing of the canteen samples and there was one woman supervisor. All the field workers were experienced in some kind of survey work, but before the study began they obtained experience of food surveying by the collection of food information from twenty-five mothers in Tottenham. This was made possible by Dr G. Hamilton Hogben, Area Medical Officer, Tottenham. The two field workers who collected the information on out-of-factory activities were trained for a fortnight before going into the field.

\section{Intake of calories and nutrients. Method of calculation}

Energy and nutrient values were calculated from Nutritive Values of Wartime Foods (Medical Research Council: Accessory Food Factors Committee, 1945) and Chemical Composition of Foods (McCance \& Widdowson, 1946), and from recipes compiled in accordance with present food habits. The vitamin $\mathrm{A}$ and carotene values are expressed as preformed vitamin $\mathrm{A}$, and allowance has been made for the cooking losses of vitamins, as recommended in Nutritive Values of Wartime Foods.

* An attempt was made by Mr R. M. Belbin, Medical Research Council Applied Psychology Research Unit, to assess the various jobs in terms of the tempo of the work and of the heaviness of the parts handled, and to ascertain whether these factors had any relation to calorie intake. The jobs proved too complex to make this possible, and he got only negative results. Details are therefore not being published. 


\section{Assessment of proportion of calorie intake spent on various activities}

A principal object of the investigation was to assess the proportions of the energy intake spent on basal metabolism, specific dynamic action, out-of-factory activities, and work. These values were calculated for the men grouped according to age (Io-year groups) and heaviness of work (light, light to medium, medium to medium heavy, and heavy). An allowance of $\mathrm{I} \cdot \mathrm{I} \mathrm{Cal}$./min was made for basal metabolism, with a deduction of $10 \%$ for the time spent asleep (based on Robertson \& Reid, 1952). The allowance for specific dynamic action was $6 \%$ of that for basal metabolism.

To estimate the energy spent on out-of-factory activities, the activities were grouped as shown in Table 2, and the mean time spent during the survey week on each of them was calculated from the total time spent on them by all the individual men in each

\section{Table 2. Classification of activities and average number of calories expended on them by the 152 men}

(Basal metabolism is included, the allowance for it being I'I Cal./min)

\section{Activity}

Dressing, including washing and shaving

Sitting, including time spent at meals

Standing, including waiting

Walking, including shopping and pushing pram

Cycling

Domestic work, light household and mechanical repairs, including motor driving

Gardening

Light games, such as darts and billiards

Athletic games and dancing

Lying down, including reading in bed

Fetching and carrying, e.g. loading lorry, shifting crates, stacking chairs

Sleeping
Average amount of energy expended* (Cai./min)

3.6
1.6
1.9
4.5
7.0
3.5
5.0
2.5
5.0
$1 \cdot 1$
5.0
1.0

* Based on rates of energy expenditure provided by Dr Passmore (see below).

group. Estimated rates of energy expenditure for the activities listed in Table 2 were provided by Dr R. Passmore and are based on results of indirect calorimetry with the Kofranyi-Michaelis respirometer, from a laboratory study (Passmore, Thomson \& Warnock, I952), and from a field study in a coal-mining district in Scotland (unpublished). The energy spent on out-of-factory activities was then calculated as the product of the time spent on the various activities with the rates of energy expenditure provided by Dr Passmore. The estimated energy spent on basal metabolism, specific dynamic action and out-of-factory activities was totalled and subtracted from the energy intake calculated from the food consumption. The difference was taken to be the energy spent at work, which, divided by the number of minutes spent at work, gave the calorie expenditure per minute at work.

\section{Clinical findings}

RESULTS

There was no clinical evidence of deficiency disease, the nutritional condition of the men being assessed clinically as good. The haemoglobin and pseudo-cholinesterase values, and the blood pressures, heights and weights were all in the range accepted as 
normal (Table 3). There are insufficient other data available for assessment of the skinfold measurements.

\section{Food consumption and intake of calories and nutrients}

For the $15^{2}$ men surveyed, Table 4 shows the average weekly consumption of various foods, and Table 5 the average daily intake of calories and nutrients. The dietary patterns differed somewhat at different ages and with the heaviness of the work done, the principal variations being: with increasing heaviness of work a rise in cheese and fish consumption and a fall in fruit consumption, and with increasing age a rise in fish consumption and a fall in that of breakfast cereals, fruit, preserves, sweets, soups and pickles.

Table 6 shows the number of calories per oz. of food eaten by men of different ages and doing work of different degrees of heaviness; it increased with both increasing age and heaviness of work.

Correlation coefficients between the haemogiobin values and the dietary intakes of iron and animal protein were calculated; they were 0.096 and 0.103 , respectively, and were not significant at the $5 \%$ level.

\section{Calorie intakes for different kinds of work and calorie expenditures for various activities}

The average daily calorie intake of men doing light work was $3269 \mathrm{Cal}$, light to medium 3446 , medium to medium heavy 3476 , and heavy $3903 . *$ For men aged 20-29, the average daily intake was $3593 \mathrm{Cal}$, for those aged 30-39 3510 and for those aged 40 or more 3432 . For the whole group, basal metabolism and specific dynamic action accounted for $46 \%$ of the calorie intake, out-of-factory activities for $22 \%$ and work for $32 \%$. The proportions differed from group to group; thus men doing light work spent $26 \%$ of their energy intake at work and those doing heavy work $41 \%$ (Table 7).

Table 8 shows the calorie expenditure per minute on work, over and above that required for basal metabolism, for the different grades of work. For men of all ages, the calorie expenditure was $2.2 \mathrm{Cal}$./min for light work, 2.7 for light to medium, 2.6 for medium to medium heavy, and 3.8 for heavy, the calorie expenditure per minute for heavy work being thus nearly twice that for light work.

Table 9 shows the time spent by men doing different grades of work on the activities listed in Table 6 . The bottom line but one of the figures in Table 9 shows for the group as a whole the percentage of the total time spent on each activity. Working and sleeping accounted for $63.3 \%$ of the total time and sitting for a further $21.6 \%$. Dressing and doing domestic work and light household and mechanical repairs each accounted for $3.8 \%$ of the time and walking for $2.1 \%$. Each of the other activities accounted for less than $2 \%$. Of the total energy spent on out-of-factory activities shown in the last line of Table 9, dressing, sitting, walking, cycling and domestic work accounted for $88 \%$. The importance of such activities becomes apparent from studies of this kind.

* The average daily calorie intake of all 137 men included in this part of the study was 3512 Cal. compared with 3549 for all 152 men included in the food survey. 
Table 3. Average clinical, anthropometric and biochemical values for the men medically examined, analysed according to age and heaviness of work

\begin{tabular}{|c|c|c|c|c|c|c|c|c|c|c|c|}
\hline \multirow[b]{3}{*}{ Attribute measured } & \multicolumn{7}{|c|}{$\begin{array}{l}\text { Average values subdivided ac- } \\
\text { cording to grade of work }\end{array}$} & \multirow{2}{*}{\multicolumn{4}{|c|}{$\begin{array}{l}\text { Average values subdivided } \\
\text { according to age in years }\end{array}$}} \\
\hline & \multicolumn{3}{|c|}{ Whole group } & & \multicolumn{3}{|c|}{ Medium } & & & & \\
\hline & $\begin{array}{l}\text { No. of } \\
\text { subjects }\end{array}$ & $\begin{array}{c}\text { Average } \\
\text { value }\end{array}$ & $\begin{array}{l}\text { Standard } \\
\text { deviation }\end{array}$ & Light & $\begin{array}{l}\text { Light } \\
\text { to } \\
\text { medium }\end{array}$ & $\begin{array}{l}\text { to } \\
\text { medium } \\
\text { heavy }\end{array}$ & Heavy & Under & $20-29$ & $30-39$ & $\begin{array}{l}40^{\circ} \\
\text { and } \\
\text { over }\end{array}$ \\
\hline Height (in.) & 151 & 67 & 3 & 67 & 66 & 67 & 68 & 68 & 67 & 68 & 67 \\
\hline Weight (lb.) & $r_{5}$ & 147 & 22 & 143 & 147 & 150 & 147 & 140 & 144 & 153 & 145 \\
\hline Skinfold (mm.) & 151 & 48 & 20 & 49 & 49 & 49 & 42 & 39 & 43 & 51 & 50 \\
\hline $\begin{array}{l}\text { Haemoglobin ( } \% \\
\text { Haldane) } \dagger\end{array}$ & 149 & 104 & 7 & 104 & 105 & I04 & ror & 104 & 105 & 105 & 102 \\
\hline $\begin{array}{l}\text { Systolic pressure } \\
(\mathrm{mm} . \mathrm{Hg})\end{array}$ & 147 & 130 & 12 & 127 & 128 & 133 & 129 & 121 & 129 & I3I & 130 \\
\hline $\begin{array}{l}\text { Diastolic pressure } \\
\text { (mm. Hg) }\end{array}$ & 142 & $8 \mathrm{I}$ & 9 & 79 & 81 & 82 & 81 & 77 & 79 & 82 & 82 \\
\hline $\begin{array}{l}\text { Pseudo-cholinesterase } \\
\text { (units) } f\end{array}$ & 130 & 106 & 24 & ro4 & 107 & 103 & I I I & II7 & 104 & 107 & 105 \\
\hline $\begin{array}{l}\text { * Sum of the five me } \\
\text { slightly flexed and supin } \\
\text { body; just below costal } \\
\text { I.4 sq.cm each; opening } \\
+ \text { Haemoglobin levels } \\
\text { a grey-wedge photomet } \\
\ddagger \text { Measurements of p } \\
\text { Establishment, Porton. } \\
\text { (cf. Berry et al. r954). } \\
\text { in } 0.5 \text { h from the blood }\end{array}$ & $\begin{array}{l}\text { asuremen } \\
\text { ated; a co } \\
\text { margin in } \\
\text { tension } \\
\text { taken fr } \\
\text { r. }\end{array}$ & $\begin{array}{l}\text { ts: front } \\
\text { orrespond } \\
\text { midclav } \\
\text { was } 170 \mathrm{~g} \\
\text { rom capil } \\
\text { holinester } \\
\text { nique use }\end{array}$ & $\begin{array}{l}\text { of arm ming point } \\
\text { dicular line } \\
\text { g rising to } \\
\text { llary blood } \\
\text { rase in plas } \\
\text { ed was one } \\
y \text { of pseud }\end{array}$ & $\begin{array}{l}\text { aidway } \\
\text { on bacl } \\
; \text { in. } t \\
360 \mathrm{~g} \text { at } \\
\text { with th } \\
\text { sma we } \\
\text { describ }\end{array}$ & $\begin{array}{l}\text { etween } \\
\text { o of arm; } \\
\text { o right ar } \\
t \text { I cm. } \\
\text { he subjec } \\
\text { re made } \\
\text { ed by Ain }\end{array}$ & $\begin{array}{l}\text { of hum } \\
t \text { below } \\
\text { elow um } \\
\text { one for } \\
\text { the staff } \\
\text { orth, Dav }\end{array}$ & $\begin{array}{l}\text { lerus and } \\
\text { angle of s } \\
\text { nbilicus. } \\
2-3 \mathrm{~min} \text {, }\end{array}$ & $\begin{array}{l}1 \text { ante } \\
\text { scapu } \\
\text { Calip } \\
\text { oxyh } \\
\text { Chem } \\
\text { utland }\end{array}$ & $\begin{array}{l}\text { ital } \\
\text { jith : } \\
\text { cont } \\
\text { roglo }\end{array}$ & $\begin{array}{l}\text { wit } \\
\text { hel } \\
\text { late } \\
\text { beir }\end{array}$ & ted \\
\hline
\end{tabular}

Table 4- Average weekly consumption of various foods eaten by the whole group

$$
\text { of } 152 \text { men }
$$

$\begin{array}{lc}\text { Food item } & \begin{array}{c}\text { Average amount } \\ \text { eaten per week } \\ \text { (oz.) }\end{array} \\ \text { Bread } & 77 \\ \text { Breakfast cereals } & 7 \\ \text { Cake and biscuits } & 20 \\ \text { Cheese } & 5 \\ \text { Cheese dishes } & 0 \cdot 6 \\ \text { Eggs } & 4 \\ \text { Fats } & 12 \\ \text { Fish } & 8 \\ \text { Fruit and nuts } & \text { I6 } \\ \text { Meat } & 31 \\ \text { Milk and cream } & 76 \\ \text { Potatoes and chips } & 62 \\ \text { Preserves } & 3 \\ \text { Soup and gravy } & \text { I1 } \\ \text { Meat stew, puddings and pies } & 10 \\ \text { Sugar } & 16 \\ \text { Fruit puddings, pies and milk sauces } & 35 \\ \text { Confectionery } & 4 \\ \text { Vegetables, greens } & \text { I2 } \\ \text { Peas, beet and other vegetables } & 19 \\ \text { Pickles and sauces } & 0 \cdot 7\end{array}$


Table 5. Average daily intake of calories and nutrients for the whole group of 152 men

\begin{tabular}{|c|c|c|c|c|c|c|c|c|c|c|c|c|}
\hline & $\begin{array}{c}\text { Calories } \\
\text { (Cal.) }\end{array}$ & $\begin{array}{l}\text { Vegetable } \\
\text { protein } \\
\text { (g) }\end{array}$ & $\begin{array}{c}\text { Animal } \\
\text { protein } \\
\text { (g) }\end{array}$ & $\begin{array}{l}\text { Fat } \\
(\mathrm{g})\end{array}$ & $\begin{array}{l}\text { Carbo- } \\
\text { hydrate } \\
\text { (g) }\end{array}$ & $\begin{array}{l}\text { Calcium } \\
\text { (g) }\end{array}$ & $\begin{array}{l}\text { Iron } \\
\text { (mg) }\end{array}$ & $\begin{array}{c}\text { Vitamin } \\
\text { A } \\
\text { (i.u.) }\end{array}$ & $\begin{array}{l}\text { Thiamine } \\
\text { (mg) }\end{array}$ & $\begin{array}{c}\text { Nicotinic } \\
\text { acid } \\
(\mathrm{mg})\end{array}$ & $\begin{array}{l}\text { Ribo- } \\
\text { flavin } \\
\text { (mg) }\end{array}$ & $\begin{array}{c}\text { Vitamin } \\
\text { C } \\
(\mathbf{m g})\end{array}$ \\
\hline $\begin{array}{l}\text { Average } \\
\text { intake }\end{array}$ & $3549^{*}$ & 54 & 55 & I 38 & 435 & I'3 & 21 & 4171 & $\mathrm{I} \cdot 7$ & 14 & 1.8 & 42 \\
\hline tandard & 620 & II & 16 & 28 & 80 & 0.3 & 4 & 2253 & 0.3 & 3 & 0.4 & I8 \\
\hline
\end{tabular}

* Including $130 \mathrm{Cal}$. obtained from beer.

Table 6. Average number of calories per oz. food eaten by $\mathrm{I}_{4} 6$ men* according to age and heaviness of work

Number of men and calorie value per oz. food eaten by men aged in years

$\overbrace{\overbrace{20-29}^{20-39}}^{30 \text { and over }}$

Light

Grade of work

Light to medium

Medium to medium

heavy

Heavy

All grades
No. Cal./oz. No.

Cal.joz.

$$
8 \mathbf{I}
$$

80

$8 \mathbf{I}$

85
IO

22

6
All ages,

No. Cal./oz. no. of men
12

12

14

85

$8 \mathbf{1}$

79

30

38

48

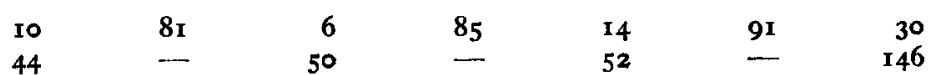

* The data for five men under 20 and one man where work was not graded are not included.

Table 7. Distribution of the average total daily calorie intake of the 137 men, whose calorie expenditure was studied, between the calories required for specific dynamic action, basal metabolism, out-of-factory activities and work

Average amount of energy and percentage of whole expended on

\begin{tabular}{|c|c|c|c|c|c|c|c|c|c|c|}
\hline & \multirow{3}{*}{$\begin{array}{c}\text { No, of } \\
\text { men }\end{array}$} & \multirow{3}{*}{$\begin{array}{l}\text { Average } \\
\text { intake } \\
\text { (Cal.) }\end{array}$} & \multicolumn{8}{|c|}{$\begin{array}{l}\text { Average amount of energy and percentage } \\
\text { of whole expended on }\end{array}$} \\
\hline & & & \multicolumn{2}{|c|}{$\begin{array}{l}\text { Specific } \\
\text { dynamic } \\
\text { action }\end{array}$} & \multicolumn{2}{|c|}{$\begin{array}{c}\text { Basal } \\
\text { meta- } \\
\text { bolism }\end{array}$} & \multicolumn{2}{|c|}{$\begin{array}{c}\text { Out-of-factory } \\
\text { activities }\end{array}$} & \multicolumn{2}{|c|}{ Work } \\
\hline $\begin{array}{l}\text { Grade of work } \\
\text { Light }\end{array}$ & & & $\begin{array}{c}\text { Cal. } \\
93\end{array}$ & $\begin{array}{c}\% \\
3\end{array}$ & $\begin{array}{l}\text { Cal. } \\
\text { I550 }\end{array}$ & $\begin{array}{l}\% \\
47\end{array}$ & $\begin{array}{l}\text { Cal. } \\
788\end{array}$ & $\begin{array}{l}\% \\
24\end{array}$ & $\begin{array}{l}\text { Cal. } \\
838\end{array}$ & $\begin{array}{l}\% \\
\mathbf{2 6}\end{array}$ \\
\hline Light to medium & 39 & 3446 & 92 & 3 & I 532 & 44 & 759 & 22 & 1063 & $3 I$ \\
\hline $\begin{array}{l}\text { Medium to medium } \\
\text { heavy }\end{array}$ & 42 & 3476 & 92 & 3 & I 533 & 44 & $8^{8} 8$ & 24 & 1013 & 29 \\
\hline Heavy & 28 & $39 \circ 3$ & 92 & 2 & I 534 & 39 & 692 & 18 & I 585 & $4 I$ \\
\hline
\end{tabular}

Table 8. Average calorie expenditure per minute by the 137 men on work, exclusive of basal metabolism, according to heaviness of work

Light

Grade of work

Light to medium

Medium to medium heavy

Heavy

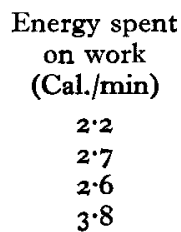

Energy spent

No. of men

28

39

42

28 
Vol. 8

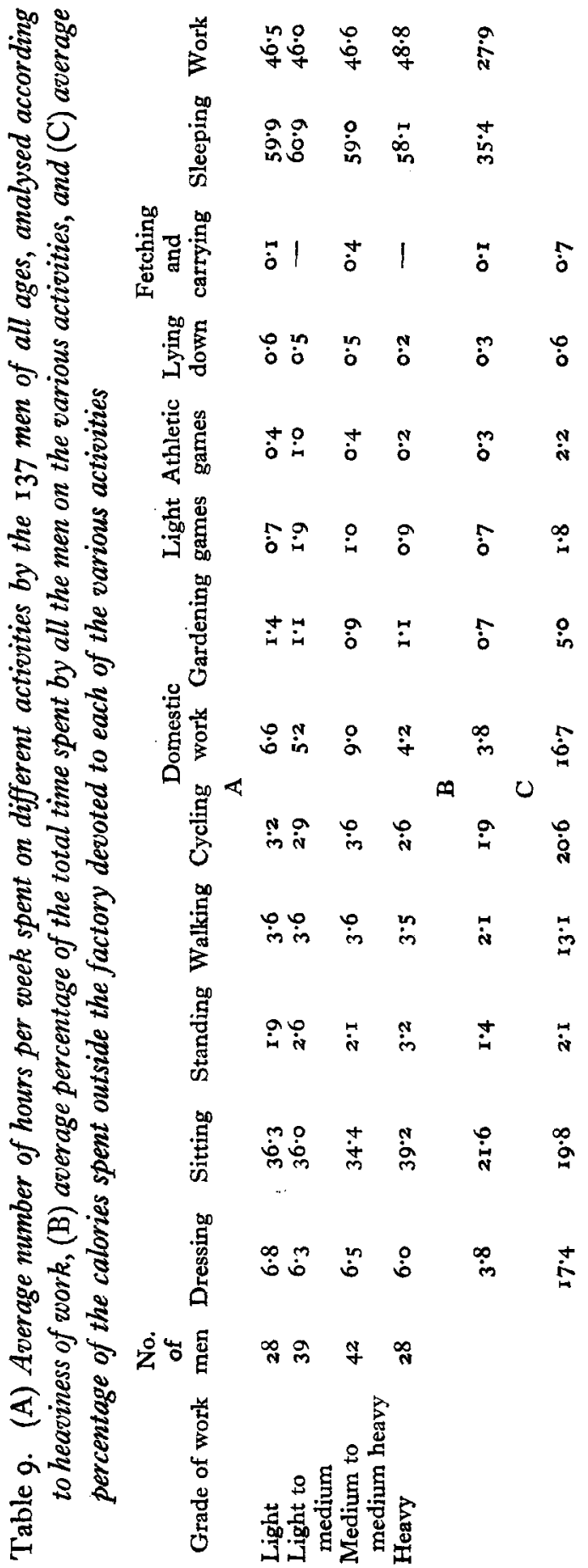




\section{DISCUSSION}

The medical examinations showed that the nutritional state of the men included in the study was good and that there were no signs of specific deficiency. The fifteen men excluded from the study of calorie intake and expenditure were not omitted because of any ascertained nutritional deficiency, but because it was thought better not to include in such a study anyone with an impairment that might possibly affect his metabolism.

The differences in calorie intake due to differences in age and in heaviness of work necessarily led to differences in the kinds and amounts of food eaten. The extra calories required by heavy workers came principally from bread and cakes, cheese, fish and potatoes, and for some men from eggs and milk. There was no greater consumption of meat by the heavy than by the light workers, although the intake of animal protein was greater. The fact that heavy workers ate more of certain foods or had a higher intake of certain nutrients than other workers does not mean that they had a special physiological need for such foods and nutrients.

It has generally been accepted that persons with high calorie requirements take the more concentrated foods, so as to avoid a too bulky diet, and the present study confirmed this, the tendency being the same for the older and for the younger men. The weight of food eaten was greater for the younger than for the older men, but more calories per oz. food were obtained by the older than by the younger, possibly because with advancing age the stomach cannot cope with so large a volume. Some of the foods for which consumption fell with increasing age were bulky, such as potatoes, soups and gravy, milk and fruit, but for some other bulky foods, among them stews and vegetables, consumption did not fall with age. Heavy workers tended to have a low consumption of stews, fruit and other vegetables, although young heavy workers took relatively large quantities of milk. A noticeable feature was the relatively high consumption by younger men of confectionery, pickles and sauces.

The intakes of all nutrients were as high as those recommended by the British Medical Association: Nutrition Committee (1950). The calorie intakes can broadly be compared with the standards of calorie intake recommended by the Food and Agriculture Organization of the United Nations: Committee on Calorie Requirements (1950). Exact comparison is not possible because the two methods of calculating calorie values are not the same. The United Kingdom method tends to credit certain foods with a relatively smaller number of calories than does the F.A.O. method. The calorie value of a diet calculated by the F.A.O. method is thus higher than when calculated by the United Kingdom method.

The Food and Agriculture Organization suggests that calorie requirements should be reduced by $7.5 \%$ of the requirement at the age of 25 for every ro years beyond that age; thus, persons aged 45 are considered to require about $15 \%$ less calories than those aged 25. The present results show a decreasing intake with age, but not to the extent suggested by F.A.O. According to the method of calculation recommended by F.A.O., the average calorie requirements of adult men in the U.K. are 3200 Cal. at 20-29 years, 2960 Cal. at $30-39$ years, and 2720 Cal. at $40-49$ years. The intakes of 3593, 35 ro and 
$343^{2}$ found in the present survey for those three age groups exceed these F.A.O. standard values. Moreover, whereas no sedentary workers were included in the present study, the average intake of 3269 Cal. by men doing light work exceeded the F.A.O. standard. The implication is, therefore, that the standards proposed by F.A.O. are too low, and still more so when account is taken of the difference in the method of calculating calorie values mentioned above.

The survey showed that, for the groups examined, heavy workers took some 600 Cal. a day more than light workers. Light workers spent $2 \cdot 3 \mathrm{Cal} / / \mathrm{min}$ at their work compared with 4.9 for heavy workers; of the total daily calorie intake, light workers spent $26 \%$ on work and heavy workers $41 \%$ (Table 7 ).

The present findings do not confirm those from a survey in Newcastle reported by the Chief Medical Officer of the Ministry of Health (Ministry of Health, 1950), in which no difference in calorie intake was found between men doing work of different grades of heaviness. The average daily intake of $3549 \mathrm{Cal}$. for all the men in Slough who were the subject of this study agreed well with that of 3406 for the men in Newcastle. The Newcastle survey was a preliminary study, and no figures provided by it would permit of analysis similar to that for the Slough results. At Newcastle the classification of the work into grades of heaviness was made by the shop foreman and the works manager, and at Slough by factory inspectors. The two sets of observers may have taken different factors into account, and this may account for the failure to show differences of calorie intake for different kinds of work in Newcastle.

The method used in the present study for allocating energy expenditure to different activities is applicable to average values for groups of men but not for individual men. Thus, the man with the lowest intake, $1918 \mathrm{Cal}$./day, was a heavy labourer aged 58 of slight physique. His out-of-factory activities were normal. Because of his low bodyweight his energy expenditure on out-of-factory activities would, by the use of average values, probably have been overestimated. The food record suggests that he was not eating normally during the survey week.

It is important also that groups whose calorie intake and expenditure are to be compared must be broadly similar in height and weight and should be similar in those respects also to groups from which the standards of energy expenditure are derived. The importance of ensuring this is demonstrated by comparing the figures for the six men with the lowest calorie intakes and the six with the highest. The six men with the low calorie intakes had much the same kind of out-of-factory activities as those with the high calorie intakes. For the men with the low calorie intakes, the energy estimated to be spent at work was about $0 . \mathrm{I} \mathrm{Cal./min}$; the corresponding figure for the men with the high calorie intake was 6.8 . The former value is obviously too low, and the latter would seem too high. Further examination of the figures showed that the average weight of the six men with the low calorie intakes was $5^{8} \mathrm{~kg}$ and that of the six with the high calorie intakes $72 \mathrm{~kg}$. If, as is likely, the energy expenditure on different activities varies with the body-weight of the subject, then the energy available for work would be underestimated for the men with low calorie intakes and overestimated for those with high calorie intakes. Fortunately the heights and weights of the various groups examined in the present study were for all practical purposes the same. 
The estimate of the calories spent on work was obtained indirectly, as the difference between the total energy intake and the estimated amount spent on basal metabolism, specific dynamic action and out-of-factory activities. Any error in any of these estimates thus directly affected the estimate of the calories spent on work. The values used for basal metabolism, specific dynamic action and out-of-factory activities should be fairly reliable, since they are based on many direct determinations of energy expenditure.

The estimates of the average calorie intakes of the groups, as calculated from food tables, are likely to be reasonably reliable also, but there may well be substantial weekly variations in intake. The effect of a wrong estimate of the calorie intake can be shown by supposing that the estimated value was $10 \%$ above the true value--say, $320 \mathrm{Cal}$./ day for men doing light work and 390 for those doing heavy work. The excess would be credited to the energy spent at work and would amount to about 0.8 and I. $\circ \mathrm{Cal} . / \mathrm{min}$, respectively. There is, however, no reason to suppose that such possible errors would fall more heavily on any one group than on any other; in consequence, differences between groups are not likely to be much affected.

The figures in Table 9, which show the average number of hours per week spent on the various activities, suggest that the men had a fairly uniform pattern of behaviour. The hours per week spent by the individuals in all groups on dressing range from $6 \cdot 0$ to $6 \cdot 8$, on sitting from $34^{\circ} \cdot 4$ to $39^{\cdot 2}$ and on sleeping from $5^{8 \cdot 1}$ to $60 \cdot 9$. Similar observations on more groups in different parts of the country could help to establish these patterns more firmly. The distribution of the calories spent on out-of-factory activities shows the importance of such activities as sitting and walking and the relative unimportance of such more active occupations as dancing and gardening.

\section{SUMMARY}

I. A previous pilot survey had suggested that calorie intake did not, on the average, vary between groups of men doing work of different degrees of activity. A further survey was, therefore, made early in 1952 of the diet and activities of men working in a number of factories in Slough on jobs of different degrees of heaviness. The number medically examined was $\mathrm{r} 74$ and information on diet and out-of-factory activities was collected for 152 of them. Results on 137 of the men who could reliably be presumed fit were used for a study of calorie intakes and expenditures. The method of calculating the number of calories spent on the various activities is described.

2. The clinical assessments showed that the nutritional state of the men was good.

3. For the group of 152 men the average daily intake of calories was 3549 Cal., protein $109 \mathrm{~g}$, fat $138 \mathrm{~g}$, carbohydrate $435 \mathrm{~g}$, iron $2 \mathrm{Img}$, calcium $\mathrm{I} \cdot 3 \mathrm{~g}$, vitamin A $417 \mathrm{r}$ i.u., thiamine $\mathrm{I} \cdot 7 \mathrm{mg}$, nicotinic acid $\mathrm{I}_{4} \mathrm{mg}$, riboflavin $\mathrm{r} .8 \mathrm{mg}$ and ascorbic acid $42 \mathrm{mg}$. The intakes of nutrients were as high as those recommended by the British Medical Association: Nutrition Committee (1950).

4. The average daily calorie intake of men doing light work was about $600 \mathrm{Cal}$./day less than that of men doing heavy work. The previous failure to differentiate between intakes was thus not confirmed. The estimated calorie expenditure per minute, excluding what was required for basal metabolism, was on an average $2 \cdot 2 \mathrm{Cal}$. for 
light work, 2.7 for light to medium work, 2.6 for medium to medium heavy work and 3.8 for heavy work. For the whole sample it was estimated that the percentage of the calorie intake spent on basal metabolism and specific dynamic action was 46 , on outof-factory activities 22 and on work 32 . The percentage spent on work varied from 26 for men doing light work to $4 \mathrm{I}$ for men doing heavy work. The tentative nature of these estimates is emphasized.

5. On an average, $27.9 \%$ of the whole day was spent at work and $35.4 \%$ in sleeping. Of the remainder, $21.6 \%$ was on an average spent in sitting, $3.8 \%$ in dressing, $3.8 \%$ in domestic work and about $2 \%$ or less in each of the other activities listed in Table 2. Of the energy spent on out-of-factory activities, $19.8 \%$ was spent in sitting, $17.4 \%$ in dressing, $20.6 \%$ in cycling, $16.7 \%$ in domestic work and $13.1 \%$ in walking, with only small proportions on other activities.

I express my warmest thanks to Dr W. T. C. Berry and Dr P. J. Cowin, who made the medical examinations, and to Dr G. Hamilton Hogben, Area Medical Officer, Tottenham, who made possible the collection by the field workers of food information from twenty-five mothers in Tottenham.

I wish to record my appreciation of the help received from the management of the factories and from the workmen and the housewives and of the participation of Dr A. I. G. McLaughlin and Mr N. L. Ford and Mr R. M. Belbin. I wish to thank Miss G. M. Warnock for assisting in the approach to the factories and the Social Survey for undertaking some of the computing.

The calculations in this paper depend mainly on the estimated energy expenditures for various activities provided by $\mathrm{Dr}$ R. Passmore, which were in large part derived from a field study in a coal-mining district of Scotland, made under the aegis of the Committee on Diet and Energy Requirements of the Medical Research Council. I wish to thank Dr Passmore for his most generous co-operation and the Committee for permission to use their data, which are still unpublished.

The field work of the study was done by Mrs A. Clark, Mrs J. Gilbert, Mr M. Goldblatt, Mrs P. Macmillan, Mrs L. McCarthy, Mr W. J. Smith, Mrs E. Terry, Mrs K. Ward and Mrs F. Weddon. It is a pleasure to acknowledge my indebtedness.

Finally, I wish to express my warmest thanks to Dr Austin Eagger and the staff of the Slough Industrial Health Service who did so much in connexion with the survey.

\section{REFERENCES}

Beltram, A. \& Bransby, E. R. (1950). Mon. Bull. Minist. Hlth Lab. Serv. 9, 777.

Berry, W. T. C., Cowin, P. J. \& Davies, D. R. (r954). Brit. F. Nutr. 8, 79.

British Medical Association: Nutrition Committee (r950). Brit. med. F. i, 54I.

Food and Agriculture Organization of the United Nations: Committee on Calorie Requirements (1950). F.A.O. Nutr. Stud. no. 5 .

McCance, R. A. \& Widdowson, E. M. (1946). Spec. Rep. Ser. med. Res. Coun., Lond., no. 235, 2 nd ed. Medical Research Council: Accessory Food Factors Committee. (r945). M.R.C. (War) Memor. no. 14. Ministry of Health (1950). On the State of the Public Health. [Cmd. 8343.] London: H.M. Stationery Office.

Passmore, R., Thomson, J. G. \& Warnock, G. M. (1952). Brit. F. Nutr. 6, 253.

Robertson, J. D. \& Reid, D. D. (1952). Lancet, 262, 940.

Widdowson, E. M. (1936). F. Hyg., Camb., 36, 269. 